\title{
Retraction: The effect of a sports chiropractic manual therapy intervention on the prevention of back pain, hamstring and lower limb injuries in semi-elite Australian Rules footballers: A randomized controlled trial
}

Wayne Hoskins ${ }^{*}$ and Henry Pollard

The journal has been informed by the authors' institution that, contrary to the statement in this article [1], the Macquarie University Human Ethics Committee did not receive an application for ethics approval for this study. As the study was conducted without institutional ethics committee oversight, this article has been retracted.

Received: 5 September 2011 Accepted: 13 September 2011

Published: 13 September 2011

Reference

1. The effect of a sports chiropractic manual therapy intervention on the prevention of back pain, hamstring and lower limb injuries in semi-elite Australian Rules footballers: A randomized controlled trial. Wayne Hoskins, Henry Pollard. BMC Musculoskeletal Disorders 2010, 11:64.

Pre-publication history

The pre-publication history for this paper can be accessed here:

http://www.biomedcentral.com/1471-2474/12/200/prepub

doi:10.1186/1471-2474-12-200

Cite this article as: Hoskins and Pollard: Retraction: The effect of a sports chiropractic manual therapy intervention on the prevention of back pain, hamstring and lower limb injuries in semi-elite Australian Rules footballers: A randomized controlled trial. BMC Musculoskeletal Disorders 2011 12:200
Submit your next manuscript to BioMed Central and take full advantage of:

- Convenient online submission

- Thorough peer review

- No space constraints or color figure charges

- Immediate publication on acceptance

- Inclusion in PubMed, CAS, Scopus and Google Scholar

- Research which is freely available for redistribution

Submit your manuscript at www.biomedcentral.com/submit 